\title{
Acute lower gastrointestinal hemorrhage originating in the small intestine
}

\author{
A. Ríos, M. J. Montoya, J. M. Rodríguez and P. Parrilla \\ Service of General Surgery and Digestive Diseases I. Department of Surgery. Hospital Universitario Virgen de la \\ Arrixaca. El Palmar. Murcia, Spain
}

\begin{abstract}
Introduction: lower gastrointestinal hemorrhage (LGIH) is generally self-limiting, and the most frequent etiologies are located at colonic level. The objective here is to analyze the diagnostic and therapeutic handling of acute LGIH when its etiology was located in the small intestine.

Patients and methods: between 1975 and March 2002, 12 acute cases of LGIH originating in the small intestine were admitted to our service. All consulted the hospital with acute rectorrhage, requiring a transfusion of at least 3 units of concentrated red blood cells. The mean age was $54 \pm 21$ years, $58 \%$ were women, and $83 \%$ had experienced previous episodes of LGIH.

Results: in eleven cases (92\%) an urgent lower and upper endoscopy was performed without locating the source of bleeding. An arteriography was indicated in 7 patients (58\%), which located the bleeding origin in 5 of them. In two cases a scintigraphy was performed, showing a Meckel's diverticulum in one patient and a normal image in another. All were operated on; in 8 cases (67\%), surgery was urgent; in 9 cases, a tumor was found, and in three additional patients, a case of Meckel's diverticulum was found, with a resection being carried out for all lesions. Histology showed a leiomyoma in 7 cases, a Meckel's diverticulum in 3 cases, a leiomyoblastoma in 1, and an angioma in the remaining case. After a mean follow-up of $132 \pm 75$ months, the leiomyoblastoma resulted in death, and there was a relapse in the case of angioma, which was successfully embolized with interventional radiology.

Conclusions: acute LGIH originating in the small intestine should be considered a possible etiology when digestive endoscopy does not locate the source of bleeding, with arteriography being a useful diagnostic technique for bleeding localization. Surgery is the definitive treatment - it confirms the etiology and rules out the presence of malignancy.
\end{abstract}

Key words: Acute lower gastrointestinal hemorrhage. Surgery. Small intestine. Leiomyoma. Meckel's diverticulum.

Recibido: $12-04-04$

Aceptado: 21-07-04.

Correspondencia: Antonio Ríos Zambudio. Avda. de la Libertad, 208. 30007 Casillas, Murcia. Fax: 968369 716. e-mail: ARZRIOS@teleline.es
Ríos Zambudio A, Montoya Tabares MJ, Rodríguez González JM, Parrilla Paricio P. Acute lower gastrointestinal hemorrhage originating in the small intestine. Rev Esp Enferm Dig 2006; 98: 196-203.

\section{INTRODUCTION}

Lower gastrointestinal hemorrhage (LGIH) constitutes a very frequent clinical problem in the developed world; in most cases it is not acute, and the cause negligible (1). On occasions, this hemorrhage is acute and represents a serious clinical problem, thus requiring a fast etiological and topographic diagnosis to allow appropriate treatment $(1,2)$.

The most frequent etiologies of LGIH are located at the colonic or anal level, and cases originating in the small intestine are not frequent (2-9\%). In the localization process, it is especially difficult to etiologically characterize hemorrhage, given that the exploration techniques at our disposal are limited in reaching the small intestine (1-6). These LGIHs originating in the small intestine have clinical and diagnostic peculiarities, which are clearly different from those of LGIHs of colonic origin, even though they have not been studied very extensively $(5,6)$.

Therefore, the objective of this study is to analyze the diagnostic and therapeutic management of acute LGIH originating in the small intestine.

\section{MATERIAL AND METHODS}

We revised all cases of acute LGIH treated in our hospital from 1975 to March 2002, referring to patients admitted to hospital because of acute rectal bleeding, and a decrease in hematocrit equal to or above 10 points, 
or those who required a transfusion of at least three concentrated units of red blood cells (2). Arterial-enteric fistulas treated by cardiovascular surgery were excluded; 175 cases of LGIH were detected that complied with these criteria, and we selected 12 patients (7\%) in whom the source of bleeding was localized in the small intestine.

Mean age was $54 \pm 21$ years (19-80 years), with a slight predominance of women $(58 \% ; \mathrm{n}=7)$. Ten (83\%) patients had had previous symptoms of LGIH, three of them (25\%) with an admission to hospital. None had a history of abdominal surgery, nor were they anticoagulated or antiaggregated. In 5 cases (42\%) bleeding was acute; however, the remaining cases reported having had mild rectal bleeding in the previous days, and a subsequent exacerbation of rectal bleeding symptoms.

The following have been analyzed: age, sex, duration, clinical onset, symptoms, complementary tests carried out, transfusional needs, need for surgery, localization of bleeding point, surgical technique applied, associated morbidity and mortality, hemorrhage control, relapse of bleeding, and outcome. Descriptive statistics have been developed for each of the variables.

\section{RESULTS}

All patients consulted the hospital for symptoms of acute rectal bleeding with blood clotting. In $4(33 \%)$ it was accompanied by an autonomic syndrome, and 3 of these had tachycardia (109-135 bpm) and hypotension $(70-80 / 30-50 \mathrm{mmHg})$ on arrival in the emergency ward. In addition, 4 patients (33\%) showed abdominal pain of colic type. None reported prior alterations in the gastrointestinal transit.

In the analysis of urgent cases, the mean figures of hematocrit were $19.2 \pm 11 \%$, and those of hemoglobin were $7.3 \pm 3.4 \mathrm{~g} / \mathrm{dl}$. All required blood transfusions, with a mean of 7 units of red blood cell concentrate $(7 \pm 5 \mathrm{U})$ per patient (Table I). In eleven cases (92\%) there was an upper and lower gastrointestinal endoscopy, which did not locate the source of bleeding. However, gastroscopy in three patients and colonoscopy in 5 did diagnose a potentially bleeding condition, but with no signs of bleeding (Table II). An arteriographic study of the upper and lower mesenteric artery was carried out in 7 cases (58\%); in one of these it was directly performed without endoscopy, locating in 5 of these a lesion that was the source of bleeding, while the two remaining cases were normal. In two

Table I. Series with pathology of the small intestine with acute LGIH in our service

\begin{tabular}{|c|c|c|c|c|c|c|c|c|c|c|}
\hline & Sex/Age & Hypotension & Transfusion & $\begin{array}{c}\text { Lower } \\
\text { endoscopy }\end{array}$ & Arteriography & Scintigraphy & Surgery & Diagnosis & Morbidity & $\begin{array}{l}\text { Evolution } \\
\text { (years) }\end{array}$ \\
\hline Case 1 & W/60 & No & 6 U.C.H. & Yes & $\begin{array}{l}\text { s.i Vascular } \\
\text { malformation }\end{array}$ & - & Urgent & Leiomyoma & No & Asymptomatic (17) \\
\hline Case 2 & W/59 & Yes & 16 U.C.H. & No & $\begin{array}{l}\text { s.i. Vascular } \\
\text { malformation }\end{array}$ & - & Urgent & Leiomyoma & No & $\begin{array}{c}\text { Asymptomatic } \\
(17)\end{array}$ \\
\hline Case 3 & W/60 & No & 6 U.C.H. & Yes & $\begin{array}{l}\text { s.i.Vascular } \\
\text { Malformation }\end{array}$ & - & Urgent & Leiomyoma & No & $\begin{array}{c}\text { Asymptomatic } \\
\text { (17) }\end{array}$ \\
\hline Case 4 & W/28 & No & 3 U.C.H. & Yes & - & - & $\begin{array}{c}\text { Non urgent } \\
\text { (persistent LGIH) }\end{array}$ & Meckel's D. & No & $\begin{array}{c}\text { Asymptomatic } \\
\text { (16) }\end{array}$ \\
\hline Case 5 & $\mathrm{M} / 42$ & No & 8 U.C.H. & Yes & - & - & Urgent & Leiomyoma & No & $\begin{array}{c}\text { Asymptomatic } \\
\text { (15) }\end{array}$ \\
\hline Case 6 & $\mathrm{M} / 73$ & No & 3 U.C.H. & Yes & - & - & $\begin{array}{c}\text { Urgent } \\
\text { (ischemic colitis) }\end{array}$ & Leiomyoma & No & $\begin{array}{c}\text { Asymptomatic } \\
\text { (15) }\end{array}$ \\
\hline Case 7 & $M / 65$ & Yes & 16 U.C.H. & Yes & $\begin{array}{l}\text { Lower right side } \\
\text { of the abdomen } \\
\text { loss without focussing }\end{array}$ & - & Urgent & Leiomyoma & Angor & $\begin{array}{c}\text { Asymptomatic } \\
(14)\end{array}$ \\
\hline Case 8 & W/80 & Yes & 10 U.C.H. & Yes & $\begin{array}{l}\text { s.i. Vascular - } \\
\text { Malformation }\end{array}$ & & Urgent & Leiomyoma & No & $\begin{array}{l}\text { Asymptomatic (8) } \\
\text { death other cause }\end{array}$ \\
\hline Case 9 & $\mathrm{M} / 22$ & No & 3 U.C.H. & Yes & - & Meckel's D. & $\begin{array}{c}\text { Non urgent } \\
\text { (persistent LGIH) }\end{array}$ & Meckel's D. & No & $\begin{array}{c}\text { Asymptomatic } \\
\text { (5) }\end{array}$ \\
\hline Case 10 & $\mathrm{M} / 19$ & No & 3 U.C.H. & Yes & Negative & Negative & $\begin{array}{c}\text { Non urgent } \\
\text { (persistent LGIH) }\end{array}$ & Meckel's D. & $\begin{array}{l}\text { Infection } \\
\text { wound }\end{array}$ & $\begin{array}{c}\text { Asymptomatic } \\
\text { (4) }\end{array}$ \\
\hline Case 11 & W/64 & No & 3 U.C.H. & $\begin{array}{c}\text { Yes } \\
\text { Intraoperative }\end{array}$ & $\begin{array}{l}\text { s.i. Vascular } \\
\text { malformation }\end{array}$ & - & Urgent & Angioma & No & $\begin{array}{l}\text { Relapse } 2 \text { years. } \\
\text { Radiological } \\
\text { embolization (4) }\end{array}$ \\
\hline Case 12 & W/79 & No & 3 U.C.H. & Yes & - & - & $\begin{array}{c}\text { Non urgent } \\
\text { (bleeding-colon } \\
\text { cancer) }\end{array}$ & Leiomyoblastoma & No & $\begin{array}{l}\text { Death due } \\
\text { to tumour (2) }\end{array}$ \\
\hline
\end{tabular}


Table II. Complementary explorations used for the preoperative diagnosis of bleeding

\begin{tabular}{|c|c|c|c|}
\hline Exploration & Localization of bleeding & No localization of bleeding & $\begin{array}{c}\text { Pathology detected potentially } \\
\text { bleeding lesions, but with no } \\
\text { signs of bleeding }\end{array}$ \\
\hline Gastroscopy (n= 11) & 0 & $11(100 \%)$ & $\begin{array}{c}3 \\
(\text { peptic ulcer } n=2) \\
\text { (duodenal diverticulum } n=1 \text { ) }\end{array}$ \\
\hline Colonoscopy $(n=11)$ & 0 & $11(100 \%)$ & $\begin{array}{c}5 \text { * } \\
\text { (Internal hemorrhoids 3) } \\
\text { (diverticulosis } n=2) \\
(\text { colitis } n=1)\end{array}$ \\
\hline Arteriography $(n=7)$ & $5(72 \%)$ & $2(28 \%)$ & 0 \\
\hline Scintigraphy $(n=2)$ & $1(50 \%)$ & $1(50 \%)$ & 0 \\
\hline
\end{tabular}

* Total number is smaller than that of pathologies, as some patients had more than one condition.

patients we performed a scintigraphy using Tc-99m-labelled red blood cells, which showed a Meckel's diverticulum in one, while the other was normal (Tables I and II).

All were operated on, $8(67 \%)$ as urgent cases and 4 in a non-urgent way (33\%). In 3 cases (25\%), a Meckel's diverticulum was found, which was excised. In the rest, the finding was a tumor of the small intestine, which was resected. In one of these cases the tumor was an angioma, and the surgeon was concerned about the possible existence of other concurrent angioma lesions, which led to the performance of an intraoperative enteroscopy, which ruled out such possibility. Morbidity was $16 \%$, which corresponds to an infection of a laparotomy wound and to a chest angina, without there being mortality (Table I). Mean hospital stay was $13 \pm 7$ days (7-35 days). In the tumoral lesions, the histological study reported a leiomyoma in 7 cases, leiomyoblastoma in one, and angioma in the remaining case.

After a mean follow-up of $132 \pm 75$ months there have been no new bleeding episodes, except in one patient operated for jejunal a angioma. In this case the jejunal angioma relapsed after two years, which was treated by selective embolization using interventional radiology, without there being any posterior sign of bleeding. The patient with a leiomyoblastoma died from tumor progression within two years of postoperative follow-up.

\section{DISCUSSION}

When faced with acute LGIH the main objective is to stabilize and establish vital support measures, and then to evaluate the possible etiology $(2,4)$, as was carried out in our series. A well-focussed clinical examination and exploration is essential $(2,4)$. In this way, etiologies of the small intestine usually occur in young people, contrary to colonic pathology, which usually occurs in the elderly $(1,4)$. Thus, in our series, the patients with Meckel's diverticulum were under 30 years of age.

The diagnostic protocols of acute LGIH include an ano-rectal exploration as a first step, to rule out a possible high source of bleeding, and a colonoscopy $(2,4,7,8)$. In etiologies of the small intestine, these three explorations are normal, or a pathology is found without signs of bleeding (7), as documented in our series after applying this protocol (Table II). Other explorations that are generally secondary acquire greater relevance in these cases. Thus, arteriography is the best diagnostic technique, with a diagnostic rate oscillating between 40 and $78 \%$ with low morbidity $(2-4 \%)(2,4,9)$. In our series the bleeding was localized in $72 \%$ of cases in which it was carried out, without related morbidity and mortality. In recent years, there has been a great technological development in interventional radiology, in the material used (flexible catheters of a smaller size and less resistance, etc.) as well as in the embolization particles, which is making its diagnostic and therapeutic use more generalized in certain pathologies (10). In our patient with jejunal angioma, the relapse was treated with embolization by radiology, as we already had a prior histological diagnosis, the patient was at high surgical risk, and surgical reintervention presented greater morbidity. However, we consider it risky to use this treatment on a tumor without histological confirmation, given that in patients with malignant tumoral pathology radical surgery can affect the patient's vital prognosis.

Scintigraphy with red blood cells labelled with Tc99 plays a poor role in the general prognosis of LGIH, and its use should be limited to testing whether there is suspicion of Meckel's diverticulum, as sensitivity and specificity in this pathology oscillates between 85 and 95\%, respectively $(4,11)$. In cases of established LGIH without bleeding, in which a colonic source is not localized, other techniques should be considered for the evaluation of the small intestine, such as enteroscopy, radiology of the small intestine, and the endoscopic capsule (12-17), although its value is limited in the acute process.

Surgery is the chosen treatment in cases in which the small intestine is localized as the source of bleeding, as it deals with acute clinical symptoms, it confirms etiology, and rules out the presence of malignancy. The problem arises if the bleeding point is not localized and it is neces- 
sary to carry out an emergency laparotomy due to hemorrhage persistence or recurrence. In these cases the etiology is suspected to be colonic, and the surgeon, in an erroneous way, might be forced to carry out a blind colonic resection. Therefore, even if the whole of the colon is full of blood, the small intestine should be checked, especially if it has blood on the inside. So it is relatively easy to localize a bleeding lesion intraoperatively in the small intestine, and we can then avoid two problems: first, unnecessary surgery on the colon, and secondly, leaving the etiology of the small intestine without treatment. When there are doubts on the presence of lesions in the small intestine during the operation, above all in generally multiple lesions (18), as occurred in our patient with angioma, the chosen diagnostic exploration is intraoperative enteroscopy $(13,19)$, as it allows to diagnose lesions which might have otherwise gone unnoticed on palpation (20).

As a general rule, the morbidity associated with urgent surgery for acute LGIH is high. However, when the etiology comes from the small intestine, morbidity is usually less, given that they are usually younger patients with less comorbidities, as observed in our series. Although there are patients who are at risk and who are elderly $(21,22)$. Therefore, the morbidity rate in our series was $16 \%$, and three patients $(25 \%)$ were over 70 years, as can be seen in table I.

The prognosis is usually excellent as most are benign lesions in the context of a young patient, and in which relapse is not frequent (3,23-25). However, up to $10 \%$ are malignant lesions with a poor prognosis, as in our case of malignant leiomyoblastoma (22,26-28).

In conclusion, we can say that acute LGIH originating in the small intestine should be considered a possible etiology when the digestive endoscopy does not locate the source of bleeding, with arteriography being a useful diagnostic technique for locating the bleeding lesion during the acute syndrome. Surgery is the definitive treatment, it confirms etiology, and rules out the presence of malignancy.

\section{REFERENCES}

1. Zuckerman GR, Prakash C. Acute lower intestinal bleeding. Part II: etiology, therapy, and outcomes. Gastrointest Endosc 1999; 49: 22838.

2. Raoul JL. Hémorragies digestives basses abondantes. Approche diagnostique et thérapeutique. Gastroenterol Clin Biol 1995; 19: 416.

3. Balén EM, Herrera J, Ariceta J, Montón S, Abascal L, Calvo A, et al. Eficacia de un protocolo de manejo de la hemorragia digestiva baja grave. Cir Esp 2003; 73: 95-103.

4. Zuccaro G Jr. Management of the adult patient with acute lower gastrointestinal bleeding. Am J Gastroenterol 1998; 93: 1202-8.

5. Lahoti S, Fukami N. The small bowel as a source of gastrointestinal blood loss. Curr Gastroenterol Rep 1999; 1: 424-30.

6. Schwesinger WH, Sirinek KR, Gaskill HV, Vélez JP, Corea JJ, Strodel WE. Jejunoileal causes of overt gastrointestinal bleeding: diag- nosis, management, and outcome. Am Surg 2001; 67: 383-7.

7. García MV, González A, López P, Gálvez C, Naranjo A, de Díos J, et al. Rendimiento de la colonoscopia precoz en la hemorragia digestiva baja aguda grave. Gastroenterol Hepatol 2001; 24: 327-32.

8. Fernández E, Linares A, Alonso JL, Sotorrio NG, de la Vega J, Artimez ML, et al. Colonoscopic findings in patients with lower gastrointestinal bleeding send to a hospital for their study. Value of clinical data in predicting normal o pathological findings. Rev Esp Enferm Dig 1996; 88: 16-25.

9. Rodríguez García JI, García Flórez LJ, Navarrete Guijosa F, Floriano Álvarez P, Martínez Rodríguez E. Hemorragia digestiva por tumoraciones yeyunoileales. Rev Esp Enferm Dig 1994; 85: 10-4.

10. Funaki B. Endovascular intervention for the treatment of acute arterial gastrointestinal hemorrhage. Gastroenterol Clin North Am 2002; 31: 701-13.

11. Lin S, Suhocki PV, Ludwig KA, Shetzline MA. Gastrointestinal bleeding in adult patients with Meckel's diverticulum: the role of technetium 99m pertechnetate scan. South Med J 2002; 95: 1338-41.

12. Van Gossum A, Hittelet A, Schmit A, Francois E, Deviere J. A prospective comparative study of push and wireless-capsule enteroscopy in patients with obscure digestive bleeding. Acta Gastroenterol Belg 2003; 66: 199-205.

13. De Franco A, Celi G, Restaino G, Foschi R, Vecchioli A, Marano P. Imaging of small bowel tumors. Rays 2002; 27: 35-50.

14. Molina Pérez E, Lamas García D, Pérez Cuadrado E. Push enteroscopy series: diagnostic and therapeutic efficacy. Rev Esp Enferm Dig 2002; 94: 259-68.

15. Rodríguez Téllez M, García Montes JM, Gómez Rodríguez BJ, Guerrero J, Herrerías JM Jr, Pellicer F, et al. Usefulness of capsule endoscopy in patients with suspected small bowel disease. Rev Esp Enferm Dig 2004; 96: 10-21.

16. Caunedo Álvarez A, Rodríguez Téllez M, Barroso Relinque N, García Montes JM, Pellicer Bautista FJ, Herrerías Gutiérrez JM. Role of capsule endoscopy in the management of patients with obscure gastrointestinal bleeding. Endoscopy 2002; 34: 685-9.

17. Ell C, Remke S, May A, Helou L, Henrich R, Mayer G. The first prospective controlled trial comparing wireless capsule endoscopy with push enteroscopy in chronic gastrointestinal bleeding. Endoscopy 2002; 34: 685-9.

18. Ledro Cano D, Pellicer Bautista FJ, Cantillana Martínez J, Esteban Carretero J, Gómez Parra M, Herrerías Gutiérrez JM. Hemorragia digestiva por hemangiomatosis difusa de intestino delgado en el anciano. Rev Esp Enferm Dig 2000; 92: 767-8.

19. Rossini FP, Pennazio M. Small bowel endoscopy. Endoscopy 2000; 32: 138-45.

20. González Conde R, Parada y Herreros R, Cobos Mateos JM, Casas Pinillos S, Gónzalez Sánchez JA, López Ríos F, et al. Hemorragia digestiva baja masiva debida a hemangioma cavernoso yeyunal no detectado por escintigrafia. Rev Esp Enferm Dig 1993; 83: 123-6.

21. Feller AA, Movson J, Shah SA. Meckel diverticulum: a geriatric disease masquerading as common gastrointestinal tract disorders. Arch Intern Med 2003; 163: 2093-6.

22. Abu-Hamda EM, Hattab EM, Lynch PM. Small bowel tumors. Curr Gastroenterol Rep 2003; 5: 386-93.

23. Varna JD, Hill MC, Harvey LA. Hemangioma of the small intestine manifesting as gastrointestinal bleeding. Radiographics 1998; 18: 1029-33.

24. Happe MR, Woodworth PA. Meckel's diverticulum in an adult gastrointestinal bleed. Am J Surg 2003; 186: 132-3.

25. Bujanda L, Beguiristain A, Galvany A, Villar JM, Arenas JI, Álvarez J. Hemorragia digestiva baja grave por divertículo de Meckel. Rev Esp Enferm Dig 1993; 84: 211-2.

26. Levy AD, Remotti HE, Thompson WM, Sobin LH, Miettintn M. Gastrointestinal stromal tumors: radiologic features with pathologic correlation. Radiographics 2003; 23: 283-304.

27. Francis A, Iqbal T, Chesner IM. Obscure gastrointestinal haemorrhage from a leiomyoblastoma. Endoscopy 1998; 30: 58-9.

28. Pérez Cabanas I, de Miguel Velasco M, Rodríguez Garrido J, Montes Díaz M, Ortiz Hurtado H. Hemorragia digestiva baja por leiomioblastoma de yeyuno. Rev Esp Enferm Dig 1991; 79: 14751. 